Izabela Florczak ${ }^{*}$, Barbara Muszyńska**

\title{
SELECTED DIFFERENCES BETWEEN CIVIL LAW AND EMPLOYMENT LAW CONTRACTS RELATED TO WORK ON THE GROUNDS OF POLISH LEGISLATION
}

\section{Introduction}

The multiplicity of work-related contracts in Polish legislation makes it generally easy to find legal differences on comparison, but difficult to justify why they create such a different legal situation for people who are parties to such contracts. The aim of this article is to present a general overview of the contracts that may constitute the basis of work on the grounds of Polish law, and the disparate entitlements they grant. It is also crucial to decide whether such disparity is or is not justified.

When the Labour Code ${ }^{1}$ was enacted in 1974, the differences between employment and civil law obligations were clear, despite the fact that both employment and civil law regulations in Polish legal system derived from one source - the Code of Obligations adopted in 1933. Civil law contracts were created to regulate relationships between parties who are equal in their rights and economic position, while employment law regulations were set to protect the weaker party in the workplace - the employee. In the course of time work-related civil contracts have begun to be abused to avoid labour law regulations protecting the employee

* Ph.D. Student of Department of Labor Law, University of Lodz, Faculty of Law and Administration, Labour Law Chair, 90-232 Lodz, Kopcińskiego 8/12, Poland.

** Ph.D. Student of Department of Labor Law, University of Lodz, Faculty of Law and Administration, Labour Law Chair, 90-232 Lodz, Kopcińskiego 8/12, Poland.

1 OJ 2014,See: item 1502 with further changes; hereinafter referred to as LC. 
as the weaker party to employment relations. This is caused, e.g. by high costs of employment. Work performed under civil law contracts is still cheaper than that performed under employment contracts, when it comes to the costs of social security. Another reason is employers' conviction that their decisions and businesses are constrained by numerous and detailed provisions of employment law. Nowadays, Polish labour law doctrine is trying to decide whether this situation should be resolved by extending labour law regulations to civil law contracts ${ }^{2}$ or, on the other hand, by increasing the sanctions for unlawful disguise of a labour law relation as a civil law contract, which would confirm the disparity between civil law contracts and labour law contracts ${ }^{3}$.

To describe the background of this discussion it is necessary to present the main differences between civil law and employment law contracts. Also, it is crucial to provide examples of the diverse situations created by each of these contracts in the area of basic employee entitlements, as this is the main area of distinction between people who work under civil and labour law contracts.

In terms of Art. 2 Labour Code (LC), an employee is a person who is employed, among others ${ }^{4}$, on employment contract. Both the content and form of employment contract are strictly regulated by employment law. The employment relationship is regulated by the Labour Code and other employment law regulations.

In terms of Art. $300 \mathrm{LC}$, the Civil Code ${ }^{5}$ applies accordingly to employment relationship only when the given matter is not regulated by the provisions of employment law. What is more, the Civil Code cannot contravene the principles of employment law. This LC rule fills the gap in the general regulations of a legal relationship. The said solution is based on the fact that many provisions of employment law were based on civil law regulations ${ }^{6}$. The Civil Code may apply to employment relationship by defining, for example, the legal capacity, defects in the declaration of intent, and other general rules ${ }^{7}$ which are not defined in LC, as long as they are not contrary to the principles of employment law.

2 Z. Kubot, Szczególne formy zatrudnienia i samozatrudnienia, [in:] Z. Kubot (ed.), Szczególne formy zatrudnienia, Wrocław 2000, p. 32-33; Z. Hajn, Regulacja prawna zatrudniania agentów, [in:] Z. Kubot (ed.), op. cit., p. 157.

3 T. Zieliński, Umowy o zatrudnienie w aspekcie rekodyfikacji prawa pracy, [in:] Z. Kubot (ed.), op. cit., p. 55-56; P. Prusinowski, Umowne podstawy zatrudnienia, Z. Góral (ed.), Warszawa 2012, p. 43.

${ }_{4}$ Other forms of employment include: appointment, election, nomination, or co-operative employment contracts. The co-operative employment contract is a type of contract, but due to its specific characteristics it is treated as a non-contractual basis of employment. Employment contract is the only contractual form of employment.

5 OJ 2014, item 121 with further changes; hereinafter referred to as CC.

6 M. Seweryński, Polish labour law from Communism to Democracy, Warszawa 1999, p. 21.

7 W. Szubert, Zarys prawa pracy, Warszawa 1980, p. 64-65. 


\section{Employee and worker. Types of civil law contracts related to work}

In terms of the abovementioned differences between civil law and employment law relations, there is an explicit difference between the notions of employee and worker. For the purpose of this article workers are all people hired on contracts other than employment contracts. An employee is a person who works on employment contract and is, therefore, protected by employment law, as it also has an extensive protective function. A worker is a person who is obliged to work on the grounds of civil law contract. Workers are protected by employment law only where this is expressly stipulated in employment law. One example of such protection is Art. $304 \mathrm{LC}$ which obliges employers to ensure equal conditions of health and safety at work for employees and for individuals performing work on a basis other than employment contract (for example on the basis of civil law contracts) ${ }^{8}$.

Employee is supervised by the employer, while worker does not work under the supervision of the other party to the contract. Employees' subordination to the employer used to be a fundamental characteristic of employment law contract ${ }^{9}$. As the relation between employees and employers has become more flexible over the decades, subordination is no longer a determinant of employment relationship. On Polish employment market the gap in the system (the need to create a relationship that will oblige one party to work for another party without a typical supervision-subordination relation) has been filled by civil law contracts which are mostly used to create a long-lasting relation between the parties.

There is a variety of civil law contracts which can be a source of the obligation to work. The most common contract of this kind is contract for services ${ }^{10}$. Under Art. 734 Civil Code (CC) by virtue of contract for services the mandator commits the mandatary to perform a specified legal act. Contract for services, however, is not limited to the commitment to perform a legal act. It can also oblige the mandatary to perform an activity for the mandator, which in fact means that the mandatary works for the mandator, but their work, instead of being based on employment law contract, is based on civil law contract for services. Both employment law contracts and contracts for services are acts of due care. That makes their performers responsible for careful, accurate actions, not

8 T. Wyka, Bezpieczeństwo i ochrona zdrowia w zatrudnieniu niepracowniczym typu cywilnoprawnego, [in:] Z. Kubot (ed.), op. cit., p. 171-172.

9 A. Supiot, Zatrudnienie pracownicze i zatrudnienie niezależne, [in:] Referaty na VI Europejski Kongres Prawa Pracy z Zabezpieczenia Społecznego, Warszawa 1999, p. 144.

10 In the Civil Code such a contract is called ,mandate”. 
for the results of those actions ${ }^{11}$. Contract for services can create a long-lasting relation between its parties. It is a kind of contract of bilateral obligations, despite the fact that remuneration, which is an obligation of the mandator, is not essentialia negotii of contract for services ${ }^{12}$. In practice, unless otherwise stipulated in the contract, the mandatary is obliged to work while the mandator is obliged to pay remuneration for this work.

Another type of a civil law contract that can be the basis of the obligation to work is specific work contract. Under such contract the person who accepts the commission undertakes to perform a specific work, and the orderer undertakes to pay remuneration. In line with the above definition, specific work contract creates bilateral obligations by the same token as contract for services, however, in contrast to contract for services, remuneration is essentialia negotii of specific work contract ${ }^{13}$. Another difference between specific work contract and contract for services is the object of the obligation. In specific work contract the subject matter of the contract is a specified outcome. This type of contract, unlike employment contract and contract for services, is not an act of due care. In specific work contract it is the result of the services that is crucial. It is not important to the principal how the worker has achieved the result. The fact that the desired result has been achieved and passed to the orderer is the basis for paying the remuneration ${ }^{14}$.

Another type of civil law contract that may constitute the basis of the obligation to work is agency contract. Agency contract differs from the contracts mentioned above in that the agent (the person who accepts the commission), by undertaking to act on behalf of the principal when executing contracts with clients for the benefit of the principal, acts as a professional within the scope of operations of their enterprise. Agency contract regulations limit the group of entities who can take on the obligation to work to professionals. Agency contract, too, is an example of a contract of bilateral obligations. Remuneration due to the agent is one of essentialia negotii of agency contract ${ }^{15}$.

There is also an option of entering into other service contracts, which are not mentioned in CC. In such a case the provisions on contract for services apply accordingly (Art. $750 \mathrm{CC}$ ).

Several differences exist between the entitlements that Polish legislation grants to workers and employees. It is also crucial to decide, why only a group of people who work (workers or employees) benefit from such entitlements and whether such disparity is sufficiently justified.

11 Z. Radwański, J. Panowicz-Lipska, Zobowiązania - część ogólna, Warszawa 2008, p. 158; Z. Szczurek, Prawo cywilne dla studentów administracji, Warszawa 2012, p. 372.

12 Z. Radwański, J. Panowicz-Lipska, op. cit., p. 158-159.

13 Ibid., p 167.

14 J. Wiszniewski, Zarys prawa cywilnego, Warszawa 1970, p. 361.

15 Z. Radwański, J. Panowicz-Lipska, op. cit., p. 194. 


\section{Anti-discrimination rights}

Workers who are parties to civil law contracts do not benefit from the statutory right to be of equal treatment granted by LC. Prohibition against discrimination in employment, which is regulated by LC, does not apply to individuals performing work on a basis other than employment relationship. Due to the action brought against Poland by the European Commission ${ }^{16}$, Polish government adopted a statute which, among others, should protect all workers from discrimination ${ }^{17}$. The statute is a failure of Polish law. Inter alia, it does not apply to acts of discrimination that may occur when the parties enter into civil law contract. The disparity of the rules in LC and the statute can result in penalisation for discriminatory choice of an employee (under LC), but will not result in sanctions for discriminatory choice of a worker (under the statute).

The rule of equal treatment is a refinement of the general rule of equality which is considered one of the main human rights ${ }^{18}$. Under LC it is covered by Art. $11^{2}$ (the principle of equality of employees) and Art. $11^{3}$ (prohibition against discrimination in employment). Further LC regulations define equal treatment, direct discrimination, indirect discrimination, harassment, and sexual harassment. Similar definitions of the above terms are stipulated in the statute adopted in December of 2010 , but as it has already been indicated, it does not mean that protection from discrimination under LC and the statute is the same. The statute is not as strict in this matter as $\mathrm{LC}$ is.

\section{Right to rest. Working time}

What is more, CC does not provide workers with protection as regards the right to rest. Employees, according to LC, have the right to a minimum uninterrupted rest (in a 24-hour period and in a weekly period), break from work (15 minutes when their working time in a 24-hour period amounts to at least 6 hours). In addition, employees exercise the statutory right to a leave. Employees' leave is taken annually, is uninterrupted and fully paid. Workers hired under civil law contracts are not granted any of these entitlements. Of course, if they have strong bargaining power while entering into contract, they can obtain similar entitlements, but the statutory protection under LC will never apply to them.

${ }^{16}$ Action brought on $7^{\text {th }}$ of July 2010 - European Commission v Republic of Poland (Case C-341/10); Official Journal of the European Union, 25.9.2010.

17 Statute of $3^{\text {rd }}$ of December 2010 Implementing some of the European Union regulations regarding equal treatment, OJ 2010, No. 254, item 1700.

18 Z. Góral, O katalogu zasad indywidualnego prawa pracy, Warszawa 2011, p. 153-154. 
The distinction between work-related employment law and civil law contracts is also clear as regards the provisions on working time. In terms of the LC regulations, employees' working time may not exceed 8 hours in a 24-hour period and 40 hours on average in a five-day working week within a reference period not exceeding 4 months. Every hour above the limit is treated as overtime work which is, in the first place, compensated by extra free time or extra pay (by additional 50 or 100 per cent of the regular remuneration) ${ }^{19}$. In some working time systems an extra pay (or a day off) is also due to an employee who worked at night, on a Sunday or public holiday. The Labour Code also establishes a number of overtime working hours per year which cannot be exceeded.

All of the foregoing regulations do not apply to individuals who work on civil law contracts. Their working time is not limited and neither the limitation of nor the extra payment for overtime work are guaranteed by the law, but can be stipulated in the contract.

In terms of international legislation, such as the Universal Declaration of $\mathrm{Hu}-$ man Rights ${ }^{20}$, International Convent on Economic, Social and Cultural Rights ${ }^{21}$ or the European Social Charter ${ }^{22}$ the disparity between the break entitlements available to workers and employees is not justified. These sources of international law establish the right to rest and leisure for all working people without any distinction based on the source of their obligations. Taking the above into consideration it has to be indicated that de lege lata situation on Polish labour market, which creates two groups of people who work - those who have the right to rest and be protected by the limits of overtime work, and those who do not enjoy those rights, does not meet the international standards.

\section{Right to remuneration}

Article $13 \mathrm{LC}$ establishes the rule of fair remuneration. Although the term "fair" is not defined, the term "lowest amount of remuneration" is. Pursuant to the Constitution of the Republic of Poland (Art. $65.4^{23}$ ), employees enjoy the right

19 M. Rycak, Czas pracy, rozdz. XII, § 60 (pojęcie i instytucje dotyczące czasu pracy), pkt II (wymiar czasu pracy), [in:] J. Stelina (ed.), Prawo pracy, Warszawa 2013, p. 315-316.

20 Art. 24 - Everyone has the right to rest and leisure, including reasonable limitation of working hours and periodic holidays with pay.

${ }_{21}$ Art. 7 (d) - The States Parties to the present Covenant recognise the right of everyone to the enjoyment of fair and favourable conditions of work which ensure, in particular: rest, leisure and reasonable limitation of working hours and periodic holidays with pay, as well as remuneration for public holidays.

22 Art. 2 (5) - With a view to ensuring the effective exercise of the right to just conditions of work, the Parties undertake: to ensure a weekly rest period which shall, as far as possible, coincide with the day recognised by tradition or custom in the country or region concerned as a day of rest.

23 "A minimum level of remuneration for work, or the manner of setting its levels shall be specified by statute". 
to the minimum remuneration which is annually reviewed by the Commission composed of representatives of the government, private employers, and trade unions. In the year 2014 the minimum remuneration was defined on the level of gross PLN $1,680^{24}$. The minimum remuneration is due when employee works full-time (on average 40 hours per week). Workers are not eligible to the minimum remuneration, which gives the employing party the right to determine a compensation that can be lower than the minimum remuneration, even if the worker works on average 40 hours per week, or even more. No regulations on the minimum remuneration apply to workers whose contracts very often do not differ from employment contracts, when it comes to the obligations of the party who has to provide work. That is why it has to be raised that workers should have similar entitlements under the minimum remuneration regulations.

Art. 65.4 of the Constitution of Republic of Poland does not distinguish workers from employees as beneficiaries of this regulation, therefore there exists no justification for the legislature's failure to respond to the situation on the labour market. It has to be emphasised that over the decades the functions of employment contracts and work-related civil law contracts have become similar and that is why, in the authors' opinion, the regulations of the minimum remuneration should also cover workers.

\section{Enforcement of rights through litigation}

In case of a dispute between the parties to employment contract, which the parties cannot or have failed to resolve out of court, an employee who wants to enforce their rights has to file a lawsuit with an employment court. However, this is not a body outside the general judicial system, but one of the departments in a court of law. It is specialised in dealing with cases concerning employment relations ${ }^{25}$. What is even more important, such cases are conducted not to the general rules of civil procedure, but to a special procedure designed for this type of matters. This particular procedure for employment cases is stipulated in articles $459-477^{7}$ of the Civil Procedures Code (CPC) of the $17^{\text {th }}$ of November, $1964^{26}$. Therefore, it is part of civil procedures, but the legislature has established several crucial differences between general civil procedures and those governing employment cases. The reason for this is the specific nature of employment relations and, consequently, the need to protect the employee, who is the weaker party to

${ }^{24}$ Around 398 EUR. In year 2015 minimum remuneration will be defined at the level of gross PLN 1,750 - around 415 EUR.

${ }^{25}$ K. W. Baran, Postępowanie w sprawach z zakresu prawa pracy z kazusami, Gdańsk-Kraków 1999, p. 93-95.

26 OJ 2014, item 101 (consolidated text), hereinafter referred to as CPC. 
employment contract in the factual, social, and economic sense. As a result, they would probably be the weaker party to a lawsuit. Articles $459-477^{7}$ CPC create a set of procedural guarantees and privileges that should secure equal positions of both parties during legal proceedings. This aim is manifested in a few major principles, specifically: the principles of employee privilege, limited formalism, and swiftness of proceedings, which govern this procedure ${ }^{27}$.

The situation of workers who would also like to enforce their rights arising from providing work on the basis of civil law contracts is significantly different from employees. Since individuals who are parties to civil law contracts do not obtain the legal status of employees, their claims are not dealt with by employment courts, but by regular civil courts. These are the same courts that hear cases such as concerning torts, divorces, incapacitation, or a number of various civil law contracts, for instance sale contracts, tenancy contracts, etc. Therefore these courts are not specialised in disputes concerning the rights arising from one individual performing work to another individual or entity. What is more, these courts do not follow the procedural rules that apply to employment cases. On the contrary, these disputes are proceeded based on the general rules of civil procedures. In terms of these rules, parties to a lawsuit are formally equal. Since in a lawsuit most burdens rest upon the claimant, in the above-mentioned cases they actually lie with the worker. This leads to a paradox. In most cases, a person who works on civil law contract is, like employee, the weaker party of a legal relationship (factually, socially and economically). Nonetheless, as per the legal regulations, their position, including the position in a lawsuit, is equal to the position of the person who employs them. There are no privileges to support the procedural position of the worker. As a result, their position in a court of law can be actually weaker than that of the other party.

Probably the most important barrier to taking legal action are the high legal costs. For this reason, in terms of Polish law, if an employee files a claim against their employer and the value of the claim is not higher than PLN 50,000 (which is around 11,877 Euros), the employee does not need to pay the usual court fee. As for other legal actions during a lawsuit, there are fee remissions or reduced fees for employees. A claimant who is a worker, on the other hand, is obliged to pay all court fees, despite the fact that, since there is no guarantee of minimum wage for workers, they can in fact get lower remuneration than an employee who holds a similar post. In other words, they may not afford to take their case to a court of law.

Art. 466 CPC stipulates that an employee can make their claim orally in court building, instead of filing it in a paper form. Such an oral claim takes the same legal effect as a document presenting the statement of claim. It is the employee's decision which form they prefer. The only restriction is that the oral form is reserved

${ }_{27}$ M. Mędrala, Funkcja ochronna cywilnego postępowania sąowego w sprawach z zakresu prawa pracy, Lex/el, Warszawa 2011. 
for claimants who are not represented by a solicitor or legal advisor. If a case is proceeded to the general rules, the claimant - who in this case is a worker - has to file a claim in a paper form and follow strict formal provisions concerning its content. If a claim does not meet the requirements, it can be returned to the claimant with no legal effect.

Another important guarantee for employees is stipulated in Art. $477^{2}$ and Art. $477^{6} \mathrm{CPC}$. They oblige the court of first instance, if the same issues a judgement in favour of the employee, to order the verdict immediately enforceable up to an amount equal to the employee's 1-month salary. The same happens in the court of appeal with the rest of the claim, if the employee is the winning party. The reason is that in Poland earnings from employment contracts are the fundamental source of income (sometimes the only one) of employees, or even their whole families. It is reasonable to assume that remuneration plays the same role for most workers hired on civil law contracts. Therefore, it is difficult to accept that the above-mentioned guarantee does not apply to them. They have to wait until the final judgement is delivered (which means none of the parties can legally contest it any more) to make it enforceable. In practice, it can take quite a long time, even a few years.

The above-mentioned guarantees are only examples of the regulations concerning the legal procedures in employment cases. Employees enjoy a set of privileges and guarantees designed to give them a fair chance of success in a legal dispute with their employers. Even though both employees and workers face a similar, or even identical, factual and economic situation, the latter group is not granted similar procedural guarantees. Consequently, their position in court of law is, in fact, weaker than that of the party that hires them. It is also weaker than the position of employees in a similar situation. If we take into account the low stability of contractual relationship under civil law contracts and Poland's relatively high unemployment rate (almost 14 per cent at the beginning of 2014), we can conclude that the actual chances of workers enforcing their rights is dramatically small.

It should be added that there is one situation when workers enjoy the same procedural privileges as employees. In terms of Art. 22 section $1^{1}$ and section $1^{2} \mathrm{LC}$, employment on the terms and conditions set forth in LC is considered employment on the basis of the employment relationship, whatever the name of the contract concluded between the parties. Employment contracts cannot be replaced with civil law contracts where the conditions of the performance of work laid down in LC remain intact. Consequently, if the parties have concluded a civil law contract, but the conditions of this relationship are characteristic of employment contract, the worker can take their case to employment court. Such a worker can apply to the court to ascertain (confirm) the existence of an employment relationship. In terms of Art. 476 section $1.1^{1} \mathrm{CPC}$, such lawsuits are conducted to the rules specific to employment cases. This could facilitate false workers' fight 
for their rights. However, this measure can only help those workers who are actually in a bogus employment relationship. An interesting situation takes place when, as a result of a lawsuit, it is proved that the contract does fall within the civil law regime. In such a case it occurs that the dispute between parties to a civil law contract has been proceeded based on the regulations applicable to employment relations (with all the privileges designed for the party who performs work). Nevertheless, such a lawsuit remains legal and its outcome is valid. It is expressly stipulated by the provisions of law ${ }^{28}$. The rationale for such a regulation is to support the alleged employee, but it also reflects the legislature's will to prevent violations of the law. It does not, however, change the fact that workers who actually work on civil law contracts, or at least are not interested in having their employee status ascertained by the court, are in a worse position than employees when litigating to enforce their rights arising from work.

\section{Employment stability}

Next to the high costs of employment, another important reason why entrepreneurs prefer civil law contracts is that these are easy to terminate. Employment regulations supporting job security are legion, which reflects the principle of protection of employment stability that is considered to be a certain legal value that must be protected ${ }^{29}$. The intensity of this protection varies, depending on different factors. Generally, two categories of such protection are recognised in literature and jurisprudence: general protection against dismissal, and special protection against dismissal. The former covers the general provisions that must be followed when dismissing people. The latter means that termination of employment contracts of certain groups of employees is subject to certain restrictions due to their specific private, family or social situation ${ }^{30}$. There is no similar protection against termination of the legal relationship in the civil law regime. The process of terminating both types of relationships is worth a closer look.

General protection against dismissal consists of a few elements. Most of all, it concerns employees who work on indefinite contracts which are considered to create typical and the most stable employment relationships ${ }^{31}$. However, some elements of this protection can be identified with respect to fixed-term contracts as well.

28 Judgement of the Supreme Court of 15th of November 2006, I PK 98/06, OSNP from 2007, No. 21-22 item 309; judgement of the Supreme Court of 9 September 2004, I PK 659/03, OSNP from 2005, No. 10, item 139; P. Prusinowski, Rozstrzyganie indywidualnych sporów ze stosunku pracy, Z. Góral (ed.), Warszawa 2013, p. 62.

29 A. M. Świątkowski, Zasady prawa pracy, Warszawa 1997, p. 89.

30 A. Dral, Powszechna ochrona trwatości stosunku pracy. Tendencje zmian, Warszawa 2009 , p. 36.

31 J. Wratny, Problemy ochrony pracowników w elastycznych formach zatrudnienia, „Praca i Zabezpieczenie Społeczne”, 7/2007, p. 2; A. Dral, op. cit., p. 34. 
First of all, in terms of Art. $38 \mathrm{LC}$ the employer has an obligation to consult the intended dismissal with the enterprise trade union. Specifically, this means that the employer must give a written notice to the trade union representing the employee of the intent to terminate their indefinite employment contract, and must provide the reasons for such termination. If the employee is not a member of any trade union operating within the enterprise, then they can ask one of the unions to represent them. If the trade union decides that termination of employment is unjustified, it may, within a fixed period of time, present the employer with reasonable objections. The employer must consider the opinion presented by the union. However, the final decision whether to dismiss a person or not is made solely by the employer ${ }^{32}$.

The next aspect of general protection is the requirement to specify just cause of dismissal. Pursuant to Art. 30 section 4 LC, the notice of termination of an indefinite employment contract given by the employer must provide the reasons for termination. There exists no list of legal reasons for termination of employment with notice ${ }^{33}$. Polish Supreme Court has indicated examples of such situations, inter alia insolvency of the employer, redundancy, employee's misconduct ${ }^{34}$. However, the reason for dismissal must be real, not ostensible ${ }^{35}$. Furthermore, the Supreme Court has ruled that termination is inadmissible even when the given reason for termination was true, but because of its importance or nature it did not suffice to give an effective notice ${ }^{36}$. The rationale behind Art. 30 section $4 \mathrm{LC}$ is that the employee must know the employer's arguments against them, or what was the reason for this particular personnel decision. Therefore, it enables the employee to decide whether to appeal to the labour court against their dismissal ${ }^{37}$. Moreover, based on the cause given, the labour court can examine and evaluate the facts and circumstances that contributed to the termination of the contract and rule whether it was unlawful or not ${ }^{38}$.

An important guarantee, without which the above mentioned regulations would be meaningless, is the possibility of a judicial review of the termination of employment. Moreover, the case is proceeded based on special rules, favourable to the employee, as described herein above. The labour court, upon request from the employee, examines whether dismissal was defective ${ }^{39}$, i.e. whether termination

32 T. Liszcz, Prawo pracy, Warszawa 2012, p. 154.

33 There is such a list in case of dismissal without notice in Art. 52, Art. 53, and Art. 55 LC.

34 Judgment of the Supreme Court of $27^{\text {th }}$ of June 1985, III PZP 10/85, OSNCP from 1985, No. 11, item 164.

35 Judgment of the Supreme Court of $17^{\text {th }}$ of October 2006, II PK 31/06, Lex, No. 950617.

36 Judgment of the Supreme Court of $7^{\text {th }}$ of October 2009, III PK 34/09, Lex, No. 560866.

37 K. Jaśkowski, Komentarz aktualizowany do art. 30 Kodeksu pracy, [in:] K. Jaśkowski, E. Maniewska, Komentarz aktualizowany do ustawy z dnia 26 czerwca $1974 \mathrm{r}$. Kodeks pracy (Dz.U.98.21.94), Lex/el 2014.

38 Judgment of the Supreme Court of $15^{\text {th }}$ of February 2002, I PKN 901/00, Lex, No. 564464.

39 T. Liszcz, Odpowiedzialność odszkodowawcza pracodawcy wobec pracownika - cz. 1, „Praca i Zabezpieczenie Społeczne”, 12/2008, p. 4-5. 
of the indefinite employment contract was unjustified or violated the provisions of law on termination notices ${ }^{40}$. In such a case, the court alternatively declares the notice of termination ineffective (or if the contract has already been terminated - orders reinstatement of the employee in their job on the previous terms and conditions), or awards compensation ${ }^{41}$. It is basically up to the employee what they will claim for in a lawsuit ${ }^{42}$. The compensation is due in the amount of the remuneration for the period of 2 weeks to 3 months, though not less than the remuneration for the period of notice (Art. $47^{1} \mathrm{LC}$ ). Accordingly, the compensation amount is limited and is not closely related to the damage suffered by the employee. This compensation is of a specific nature and does not correspond to the classical formula of damages known in civil law ${ }^{43}$. Additionally, compensation for unfair dismissal performs a social function by providing the employee with livelihood. It also has a repressive function, since it should be a punishment for the employer for violating labour law ${ }^{44}$.

The notice period is also considered an element of the general protection of employment stability. It concerns both definite and indefinite contracts. However, notice periods in the latter cases are more diverse and adjusted to the duration of employment. In terms of Art. 36 section 1 LC they are 2 weeks, 1 month or 2 months, depending on how long a person has been working for the given employer. For fixed-term contracts, the notice period is 2 weeks ${ }^{45}$. Furthermore, the said notice periods are the minimum ones. The parties are entitled to prolong them in the contract. An employment relationship ends on the day when the period of notice expires. In this way the person involved does not lose the opportunity to make a living overnight, but has some time to prepare themselves for a new situation ${ }^{46}$. What is more, there is a method of counting the period of notice that favours dis-

40 Termination with notice of a fixed-term employment contract does not require giving the reasons for dismissal, therefore its defectiveness can only concern infringement of the regulation on dismissals.

${ }^{41}$ An employee for a fixed-term period can, in most cases, only request compensation, not reinstatement (Art. $50 \mathrm{LC}$ ).

${ }^{42}$ There are, however, some situations in which court can only award compensation. See: Art. 45 section 2 and 3 LC.

43 A. Rycak, Powszechna ochrona trwałości stosunku pracy, Lex 2013.

${ }_{44}$ Ł. Pisarczyk, Odszkodowanie z tytulu wadliwego wypowiedzenia lub rozwiazania umowy o prace przez pracodawce, „Praca i Zabezpieczenie Społeczne”, 8/2002, p. 18-19; judgment of the Polish Constitutional Tribunal of $18^{\text {th }}$ of October 2005, SK 48/03, OTK-A 2005, No. 9, item 101.

${ }_{45}$ But in this case some additional conditions must be followed to make a termination with notice permissible, see: Art. 33 LC.

46 Termination notice is a typical way of ending employment contract. However, it can also be terminated (by any party) without notice. It has an immediate effect. There is an exhaustive list of situations in which it is allowed by the employer, connected to the loss of ability or qualifications to perform work or serious violation of the employee's basic duties (Art. 52 and Art. 53 LC). Likewise, an employee can instantly end an employment contract in certain cases (Art. 55 LC). 
missed employees. Pursuant to Art. 30 section $2^{1} \mathrm{LC}$, the notice period of one or more weeks always ends on a Saturday, and the notice period expressed in months ends on the last day of the month. Consequently, if an employee is given notice, for instance, on the $7^{\text {th }}$ of July and their notice period is one month, their employment will actually terminate on the $31^{\text {st }}$ of August (not on the $7^{\text {th }}$ of August).

Finally, in accordance with Art. 30 section 3 LC, the notice of termination of employment contract by either party must be made in writing. While a failure to comply with this regulation by the employee does not actually bear any consequences, it is reverse for the employer. Moreover, the termination notice given by the employer must include information on the employee's right to appeal to labour court (Art. 30 section 5 LC). If the employer does not meet these requirements, the termination notice is still legally effective, but the employee can successfully appeal against it on the grounds of violation of the law concerning dismissals ${ }^{47}$. The said regulation applies to both indefinite and fixed-term contracts.

Perhaps even more burdensome for the employer is special protection against dismissal. As mentioned earlier, this kind of protection is related to employees who are at a particular risk of losing their job because of their family or private situation, or certain social functions they perform. This type of protection can apply in one of two variants. In the first one, the employer cannot give notice to a person for the duration of their particular situation that justifies such protection $^{48}$. This applies, inter alia, to pregnant women, employees in pre-retirement age or employees on leave or during other justified absence from work for a certain period. The second variant of protection consists in prohibition of dismissal without consent of a certain body or authority. For instance, the employer cannot give notice to a member of the board of an enterprise trade union, unless this board consents to $\mathrm{it}^{49}$. The employer who infringes the rules on special protection against dismissal may be sued by the employee.

The foregoing examples demonstrate that employees enjoy quite secure employment. Hence, the discretion of employers in creating their employment policies is to some extent limited. Therefore, employers who hire people on civil law contracts avoid a number of legal restrictions and pitfalls. At the same time, such entrepreneurs enjoy financial advantages - not only because they do not have to pay remuneration to employees they no longer need, but also they do not risk bearing the costs of possible lawsuits and compensations. Employment on civil

${ }_{47}$ Z. Góral, Komentarz do art. 30 Kodeksu pracy, [in:] K. W. Baran (ed.), Kodeks pracy. Komentarz, WKP 2012, Lex.

48 Sometimes even the possibility of termination of an employment without notice is restricted - in case of a pregnant woman, maternity leave, paternity leave and parental leave (Art. 177 and further, LC).

49 More detailed regulations in that matter are found in Art. 32 Trade Unions Act of 23 May, 1991, OJ of 2014, item 167. 
law contracts is much more flexible, which means that it can be easily and quickly terminated by either party. However, in practice, it is the employing party that mostly benefits from such a situation. Taking into account the shortage of work, people are unlikely to resign from their jobs willingly. As a result, workers on civil law contracts are particularly vulnerable to dismissal, as well as to abuse by the employing party. What is more, workers face problems arising from job insecurity, also outside their workplace. For instance, they have difficulty in obtaining a loan since they are not creditworthy.

One exception is the agency contract. Art. $764^{1} \mathrm{CC}$ stipulates that an indefinite agency contract can be terminated with notice by either party. The minimum periods of notice are prescribed and depend on the duration of the contract (they range from 1 to 3 months). Statutory notice periods cannot be shortened, but they may be extended in the contract. This is, therefore, an ordinary way of terminating a legal relationship between the parties to indefinite agency contract ${ }^{50}$. Furthermore, other civil law contracts can include provisions providing some kind of protection against unfair or immediate termination of the legal relationship. Introduction of such provisions depends on the parties and, in fact, the negotiating position of the person applying for a job. As a result, with the exception of top-level managers and skilled professionals, workers are very unlikely to enjoy comparable protection against dismissals that is available to employees.

\section{Conclusion}

From the social point of view, there are no good reasons for leaving workers on the employment market without legal protection that might improve their weaker position vis-à-vis employers. Each working individual should have the right to fair remuneration, the right to rest and protection against discrimination or sudden unfair dismissal. They should also have equal opportunities when they want to defend their rights in court. These rights should not depend on the contract on which they provide work. As stated in Polish doctrine of labour law ${ }^{51}$, given that the profound economic transformations in Poland have entailed profound labour market transformations, Polish legislature should stop avoiding the process of granting workers the rights equal to those available to employees ${ }^{52}$. The context of

${ }^{50}$ K. Kopaczyńska-Pieczniak, Komentarz do art. 764(1) Kodeksu cywilnego, [in:] A. Kidyba (ed.), Kodeks cywilny. Komentarz. Tom III. Zobowiazania - częśś szczególna, Lex 2010. It can also apply to a fix-term agency contract provided it has been transformed into a non-fixed term contract, see: Art. 764 and $764^{1}$ section 4 CC.

${ }_{51}$ Not only Polish doctrine of labour law presents this point of view. Similar conclusions are presented by T. Gyulavári, A bridge too far? The Hungarian regulation of economically dependent work, "Hungarian Labour Law E-Journal", 1/2014, p. 22.

52 Z. Hajn, Regulacja prawna zatrudnienia agentów, [in:] Z. Kubot (ed.), op. cit., p. 159. 
industrial relations is changing, which is why the traditional concept of labour law protection techniques should be re-considered ${ }^{53}$. The issue of extending labour law protection was observed in the theory of labour law a long time ago ${ }^{54}$. While the role of the law is to protect all working individuals, irrespective of the basis of their obligation to work or the type of contract ${ }^{55}$, it seems unreasonable that Polish law sustains the disparity between the entitlements granted to people who work, or ignores the situation of some of them on the employment market.

On the other hand, and this is the statement shared by the authors of this paper, extending labour law regulations to civil law relationships may ruin labour law as a field of law. Labour law relations will not be competitive, if workers working on civil law contracts are granted the same entitlements as employees. The essence of civil law contracts, subject to certain limitations ${ }^{56}$, is the freedom of contract. The rule of contractual freedom should not be limited in more cases than stipulated in the current statute. Independent civil law contracts related to work (services) are an indispensable part of economic freedom. The actual problem in the field of employment is the disguising of labour law relationships as civil law contracts. Even though a plethora of regulations have been enacted to prevent such misuse of civil law contracts (such as financial sanctions in the Labour Code, the power of State Labour Inspection to impose a fine, or the option of ascertaining the existence of a labour law relationship when the work is done under a misused civil law contract), such misuses are still very common. There are many reasons for this. The main reason is that the demand for employment exceeds the supply offered by employers, as well as the high costs of work, as has already been mentioned herein above. What is more, the definition of labour law relationship, which dates back to 1996, does not fit the new economic reality ${ }^{57}$. The necessity to prove the existence of employment relationship (by proving that work has been provided under the supervision of the employer and at the location and time specified thereby) does not meet the current needs of the employment

${ }_{53}$ M. Tiraboschi, O. Rymkevitch, The Regulation of Temporary Agency Work at European Union Level: Problems and Perspectives, [in:] T. Davulis, D. Petrylaite (ed.), Labour and Social Security Law in the XXI Century: Challenges and Perspectives, p. 309; P. Leighton, M. Wynn, Classifying Employment Relationships - More Sliding Doors or a Better Regulatory Framework?, "Industrial Law Journal", March 2011, Vol. 40, No. 1, p. 41-44.

54 P. L. Davis, Zatrudnienie pracownicze i samozatrudnienie $w$ świetle common law, [in:] Referaty na VI Europejski Kongres Prawa Pracy i Zabezpieczenia Społecznego, Warszawa 1999, p. 201.

55 A. Supiot, op. cit., p. 171.

56 According to Art. $353^{1} \mathrm{LC}$ there are three limits to the freedom of contract:

- the content or purpose of the contract is not contrary to the nature of the relationship;

- the content or purpose of the contract is not contrary to the law;

- the content or purpose of the contract is not contrary to the principles of community life.

57 Z. Góral, Najnowsze tendencje w polskim prawie pracy na tle integracji europejskiej, Prace Naukowe Wydziału Administracji, Zeszyty Naukowe vol. 23, Szkoła Wyższa im. Pawła Włodkowica w Płocku, p. 212. 
market. The market has transformed to the extent that employee mobility is replacing the strict bond between the employee and the employer. It is obvious that inasmuch as work provided on civil law contracts is provided on the same terms and same conditions as that provided on labour law contracts, there is no justification for the existing disparity between the entitlements granted to working people. It seems, however, that there are more arguments in favour of the idea to ensure more effective enforcement of the regulations that prohibit the misuse of civil law contracts than in favour of extending labour law regulations to workers who are parties to civil law contracts. 